\title{
The correlation between the intake of lutein, lycopene and $\beta$-carotene from vegetables and fruits, and blood plasma concentrations in a group of women aged 50-65 years in the UK
}

\author{
BY K. JOHN SCOTT ${ }^{1}$, DAVID I. THURNHAM ${ }^{2}$, DAVID J. HART ${ }^{1}$, \\ SHEILA A. BINGHAM ${ }^{3}$ AND KEN DAY \\ 'Nutrition, Diet and Health Department, Institute of Food Research, Norwich Research Park, \\ Colney, Norwich NR4 7UA \\ ${ }^{2}$ Human Nutrition Research Group, Department of Biomedical Sciences, University of Ulster, \\ Coleraine, Co. Londonderry BT52 ISA \\ ${ }^{3}$ Dunn Clinical Nutrition Centre, Hills Road, Cambridge CB2 $2 D H$ \\ ${ }^{4}$ Dunn Nutritional Laboratory, Downhams Lane, Milton Road, Cambridge CB4 IXJ
}

(Received 14 March 1995 - Revised 24 May 1995 - Accepted 8 June 1995)

\begin{abstract}
The correlations between the mean of $4 \mathrm{~d}$ weighed intakes of lutein, lycopene and $\beta$-carotene and mean plasma concentations during each of the four seasons were lutein $r 0.64$, lycopene $r 0.47$ and $\beta$-carotene $r 0.45$. Intake was not significantly correlated with plasma concentrations during every seasonal timepoint. There was a significantly higher intake of lutein during the spring compared with summer and autumn, lycopene intake was significantly higher during the summer and autumn and there were no significant seasonal differences in $\beta$-carotene intake. There were, however, significant seasonal differences in plasma carotenoid concentrations, the highest levels occurring between May and October. There were large inter- and intra-individual variations in intake and plasma concentrations of carotenoids. BMI was inversely correlated with plasma $\beta$-carotene $(r-0.41)$. The findings suggest that plasma carotenoid concentrations are indicative of dietary intake, but the large intra-individual variation in plasma concentrations indicates that any assessment of longer-term status from data at any one timepoint should be treated with caution.
\end{abstract}

Carotenoids: Seasonal variation in intake: Plasma concentations

Over the past decade efforts to evaluate the relationship between particular dietary factors and disease risk have gathered momentum. More recently, interest has centred on the role of antioxidant nutrients such as vitamins $C$ and $E$ and the carotenoids in the prevention of, or protection against, oxidative processes in living organisms which may be involved in the induction of disease states.

Epidemiological studies have demonstrated an inverse relationship between the consumption of vegetables and fruits and the risk of certain cancers (Steimetts \& Potter, 1991; Block et al. 1992). Vegetables and fruits are complex foods containing a wide variety of substances, some of which are widely believed to confer protective properties to human health.

The carotenoids are present in all vegetables and fruits with the exception of some root vegetables. In vitro studies have shown that certain carotenoids are capable of quenching singlet oxygen and retarding hydroperoxide formation (Terao, 1989; Di Mascio et al. 1991; Chopra et al. 1993). Human plasma is normally endowed with an array of antioxidants which includes the carotenoids. Lutein, lycopene and $\beta$-carotene are the predominant carotenoids in blood. Lutein and $\beta$-carotene are also major carotenoids in vegetables. 
In the British diet the main source of $\beta$-carotene is carrots and that of lycopene is tomatoes. Lutein occurs in a wide range of green vegetables. Unlike $\beta$-carotene, lutein and lycopene have no provitamin $A$ activity and the amount in the blood is not influenced by vitamin $A$ status.

However, the relationship between the intake of carotenoids from the diet and their concentration in the blood has not been defined adequately. Studies to investigate the diet-blood association invariably involve only a single blood measurement and, thus, do not give any information of possible long-term within-subject variation. Similarly, methods used to collect dietary information may be subject to error and give limited data on foods and, in particular, the amounts of micronutrients consumed by an individual, day-to-day variation, seasonal effects etc. Moreover, the assessment of the intake of carotenoids other than $\beta$-carotene has been hampered by the lack of adequate compositional data.

The aims of the present study were: (1) to measure for the carotenoids lutein, lycopene and $\beta$-carotene the seasonal intake from selected vegetables and fruits, and their seasonal blood concentrations, (2) to determine the relationship between the dietary intakes of lutein, lycopene and $\beta$-carotene and their concentrations in blood in order to assess the possible use of plasma carotenoid concentrations as 'biological' markers of carotenoid intake.

\section{METHODS AND MATERIALS}

\section{Subjects and sampling}

Total food intake was measured in two groups of women, one group of seventy-nine women and the other of eighty-three women, giving a total of 162 , aged between 50 and 65 years and living in the Cambridge area. They were taking in a separate study linked to the European Prospective Investigation of Cancer to assess methods of measuring food intake (Bingham et al. 1994). For the study reported here intake was measured by weight of foods eaten, using portable electronic dietary automatic scales (Cherlyn Electronics, Cambridge). Measurements were made during four successive days at four time-points during 1 year ( $16 \mathrm{~d}$ in total). These data were used to select the vegetables and fruits considered in the present study (see pp. 410-411).

Intake data from the first group of seventy-nine subjects were used to assess the contribution of particular vegetable and fruit items to carotenoid intake. In addition overnight fasting blood samples from this group were made available to the present study. Blood samples taken from forty-two subjects from this group fell within four specific time windows and corresponded to the collection of intake data. Blood samples were normally taken within 1 week of the measurement of intake. Data from these forty-two subjects were used to measure seasonal carotenoid intake and seasonal blood carotenoid concentrations. Seasonal measurements were made between November 1988 and October 1989 inclusive. The seasons were defined as winter (November-January), spring (February-April), summer (May-July), and autumn (August-October).

\section{Selection of food items}

The particular food items from which carotenoid intake was assessed were selected on the following basis. Foods were selected from food-frequency and weighed-intake data. These foods were consumed on a total of twenty or more occasions by the group of 162 subjects as a whole. These comprised seventy-two vegetable items and fifty-two fruit items. Further selection was made by omitting those items which contributed less than a total of $10 \mathrm{mg}$ $\beta$-carotene equivalents to the calculated intake of the whole group (data were calculated from McCance and Widdowson's The Composition of Foods, 5th ed.; Holland et al. 1991). Excluding mixed-vegetable salad, because of its uncertain ingredients, the selected items comprised twenty-four vegetable items and five fruit types. These twenty-four vegetable 
items contributed about $98.5 \%$ of the calculated $\beta$-carotene equivalents and the five fruit types contributed $63 \%$ of the calculated $\beta$-carotene equivalents provided by seventy-two vegetable and fifty-two fruit items respectively.

\section{Blood samples}

Sampling was carried out in accordance with approved ethical criteria, as described previously (Bingham et al. 1994). Following collection of the blood and separation of the plasma, the plasma was initially stored for up to 3 weeks at $-20^{\circ}$ after which it was stored at $-40^{\circ}$ for up to 6 months before analysis.

\section{Analytical methods}

Carotenoids in foods were measured by HPLC analysis as described previously (Hart \& Scott, 1995). This involved extraction with tetrahydrofuran and methanol and, where appropriate, saponification with methanolic $\mathrm{KOH}$. The extracts were analysed on a reverse-phase HPLC column system, comprising a $10 \mathrm{~mm}$ Spherisorb ODS 2 metal-free guard column $(5 \mu \mathrm{m})$, with a $100 \times 4.6 \mathrm{~mm}$ Spherisorb ODS2 metal-free column $(5 \mu \mathrm{m})$ connected to a $250 \times 4.6 \mathrm{~mm}$ Vydac $201 \mathrm{TP} 54$ analytical column $(5 \mu \mathrm{m})$ (Alltech Associates, Carnforth). The mobile phase consisted of acetonitrile-methanol-dichloromethane (75:20:5, by vol.). The flow-rate was $1.5 \mathrm{ml} / \mathrm{min}$.

Analysis of carotenoids in blood plasma was carried out as previously described (Thurnham et al. 1988). Briefly this involved deproteinization with ethanol and extraction into heptane and analysis on a reversed-phase HPLC column $(100 \times 4.6 \mathrm{~mm}$ Spherisorb ODS2 ( $3 \mu \mathrm{m})$; LKB (now Pharmacia Biotech), St Albans). The column was protected by a $0.5 \mu \mathrm{m}$ re-useable frit. The mobile phase consisted of methanol-acetonitrile-chloroform (47:47:6, by vol.). The flow-rate was $1.5 \mathrm{ml} / \mathrm{min}$. This method does not separate lutein and zeaxanthin, consequently lutein plus zeaxanthin in plasma is subsequently referred to as lutein. Cholesterol was measured using the enzymic colorimetric test (cholesterol oxidase (EC 1.1.3.6) and 4-aminoantipyrine (CHOD/PAP) method; Roche Diagnostics Systems, Welwyn Garden City, Herts.).

\section{Calculation of dietary intake}

The carotenoid compositions of the food items were taken from a study on the analysis of commonly consumed vegetables and fruits in the UK (Hart \& Scott, 1995). The weight of individual food items consumed by individual subjects at each time-point was multiplied by the appropriate amount of the carotenoid (lutein, lycopene, $\beta$-carotene) in that food item.

\section{Statistical analysis of data}

Statistical analysis was carried out using Mintab 8.2 software program (Minitab Inc. Pennsylvania, USA). The variations between seasonal intake of carotenoids and between seasonal plasma carotenoid concentrations were analysed by one-way ANOVA and paired $t$ tests. The degree of association between carotenoid intake and plasma concentrations was assessed by regression analysis.

\section{RESULTS}

Total weight of all foods consumed by 162 subjects over $16 \mathrm{~d}$ was $6632.9 \mathrm{~kg}$, an average of $2559 \mathrm{~g} /$ person per d. Total vegetable intake was $696.6 \mathrm{~kg}$ or $269 \mathrm{~g} /$ person per d. Total fruit intake was $527.4 \mathrm{~kg}$ or $203 \mathrm{~g} /$ person per $\mathrm{d}$. The vegetable intake was $10.5 \%$ and fruit $7.95 \%$ of the total food intake.

The total number of food items consumed was 1054, of which 151 items were vegetable and 134 were fruit items. There were 4.36 portions of vegetables and 2.29 portions of fruit consumed on average by each person daily. 
Table 1. Contribution of selected vegetables to the intake of lutein, lycopene and $\beta$-carotene* for a group of $U K$ women aged 50-65 years $\dagger$

(Values for seventy-nine subjects; total intake represented four 4-d collections)

\begin{tabular}{|c|c|c|c|c|c|}
\hline & $\begin{array}{c}\text { Percentage of } \\
\text { consumers } \ddagger\end{array}$ & Quantity (g) & $\begin{array}{l}\text { Lutein } \\
\text { (mg) }\end{array}$ & $\begin{array}{l}\text { Lycopene } \\
\text { (mg) }\end{array}$ & $\begin{array}{c}\beta \text {-Carotene } \\
(\mathrm{mg})\end{array}$ \\
\hline Carrots: Boiled & 87 & 17470 & 40 & - & 1688 \\
\hline Raw & 37 & 2611 & 6 & - & 252 \\
\hline Tomatoes: Raw & 96 & 33821 & 26 & 994 & 140 \\
\hline Fried & 20 & 1508 & 2 & 56 & 8 \\
\hline Canned & 25 & 1807 & 2 & 101 & 5 \\
\hline Lettuce & 94 & 14639 & 94 & - & 89 \\
\hline Cucumber & 82 & 8247 & 55 & - & 18 \\
\hline Peas, boiled & 77 & 9999 & 199 & - & 55 \\
\hline Runner beans, boiled & 63 & 7461 & 47 & - & 37 \\
\hline Cauliflower, boiled & 62 & 9527 & $\operatorname{tr}$ & - & $\operatorname{tr}$ \\
\hline Brussels sprouts, boiled & 59 & 9096 & 56 & - & 37 \\
\hline Broccoli, boiled & 56 & 8438 & 164 & - & 95 \\
\hline Baked beans in tomato sauce & 52 & 8886 & 2 & 148 & 3 \\
\hline Peppers, green & 44 & 2505 & 28 & - & 16 \\
\hline Marrow, boiled & 43 & 5277 & 7 & - & 2 \\
\hline Cabbage, boiled & 35 & 8257 & 9 & - & 5 \\
\hline Leeks, boiled & 32 & 3520 & 6 & - & 2 \\
\hline Watercress & 29 & 1242 & 133 & - & 59 \\
\hline Broad beans, boiled & 27 & 2757 & 17 & - & 10 \\
\hline Spring onions & 25 & 808 & 2 & - & $<1$ \\
\hline Mix vegetables, boiled & 24 & 2317 & 23 & - & 84 \\
\hline French beans, boiled & 22 & 1872 & 11 & - & 7 \\
\hline Spinach, boiled & 18 & 2285 & 169 & - & 102 \\
\hline Parsley & 14 & 44 & 3 & - & 2 \\
\hline Total & - & - & 1101 & 1299 & 2716 \\
\hline Intake from five fruit items $\$$ & - & - & 62 & - & 71 \\
\hline
\end{tabular}

tr, trace.

* All-trans- $\beta$-Carotene.

$\dagger$ For details of subjects and procedures, see pp. $410-411$.

$\ddagger$ A consumer is defined as eating at least one portion of an item during $16 \mathrm{~d}$ collection.

$\$$ Apples, bananas, oranges, mandarins, apricots.

Table 1 shows the contribution of selected items consumed by the seventy-nine subjects to the intake of lutein, lycopene and $\beta$-carotene. It can be seen that lettuce, peas, broccoli, watercress and spinach are potentially the main contributors of lutein, together with carrots, cucumber, runner beans and brussels sprouts. However, it should be noted that the percentage of consumers (a consumer being defined as a person eating at least one portion during the $16 \mathrm{~d}$ period) varies considerably depending on the item. Thus, although, for example, watercress and spinach are very good sources of lutein they were consumed by a relatively low percentage of the subjects. The main source of lycopene was raw tomatoes which were consumed by up to $96 \%$ of subjects. The principle source of $\beta$-carotene was carrots which contributed over $70 \%$ of the $\beta$-carotene intake from the selected items. Other vegetables which were good sources of lutein also contributed. The total intake of lutein from vegetables was $1101 \mathrm{mg}$ or $0.92 \mathrm{mg} /$ person per $\mathrm{d}$, of lycopene $1299 \mathrm{mg}$ or $1.03 \mathrm{mg} /$ person per $\mathrm{d}$ and of $\beta$-carotene $2716 \mathrm{mg}$ or $2.21 \mathrm{mg} /$ person per $\mathrm{d}$. The fruits contributed an additional $62 \mathrm{mg}$ lutein and $71 \mathrm{mg} \beta$-carotene in total.

Table 2 shows the average daily seasonal intake of lutein, lycopene and $\beta$-carotene, by consumers (forty-two subjects), from food items which were sources of these carotenoids. 
CORRELATION OF INTAKE WITH PLASMA CAROTENOIDS

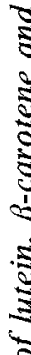

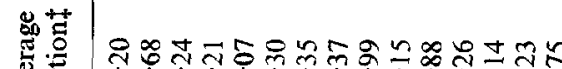

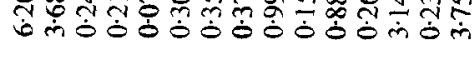

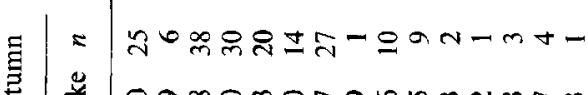

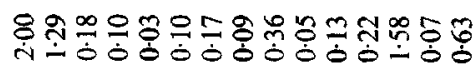

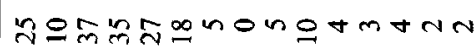

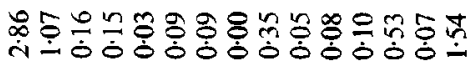

品 =

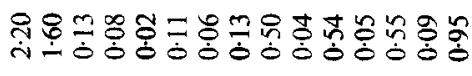

ఫ

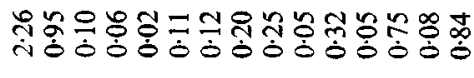

范

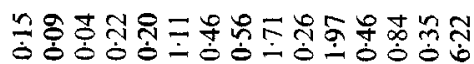

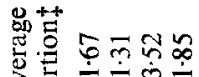

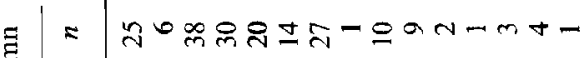

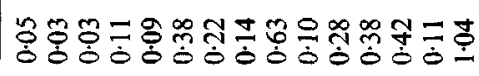

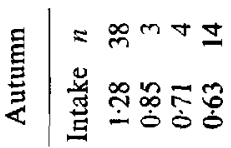

normanototmann

$2 \div$

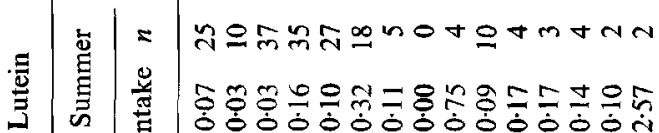

$\bar{y}=\operatorname{m} n \theta$

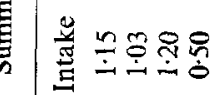

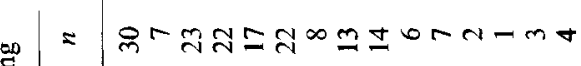

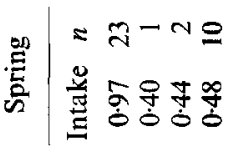

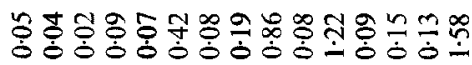

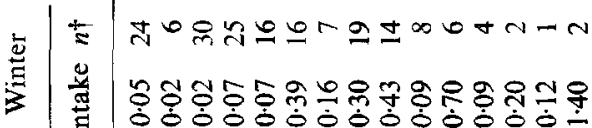

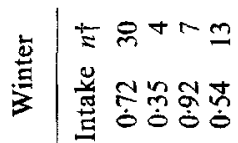

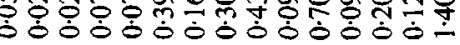
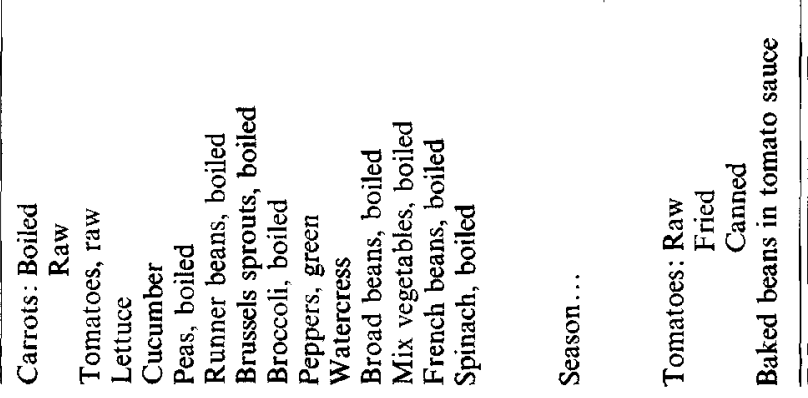
Table 3. Mean seasonal intake ( $\mathrm{mg} / 4 \mathrm{~d}$ ) by forty-two $U K$ women aged $50-65$ years of lutein, lycopene and $\beta$-carotene from all selected vegetable and fruit items*

(Mean values and standard deviations)

\begin{tabular}{|c|c|c|c|c|c|c|c|c|}
\hline \multirow[b]{3}{*}{ Season } & \multicolumn{8}{|c|}{ Lutein } \\
\hline & \multicolumn{2}{|c|}{ All vegetables } & \multicolumn{2}{|c|}{ Vegetables $\dagger$} & \multicolumn{2}{|c|}{ Fruit } & \multicolumn{2}{|c|}{ Total } \\
\hline & Mean & SD & Mean & SD & Mean & SD & Mean & SD \\
\hline Winter & $3 \cdot 21$ & $2 \cdot 59$ & $2 \cdot 53$ & 1.66 & 0.24 & $0 \cdot 19$ & $3 \cdot 45^{\mathrm{ab}}$ & $2 \cdot 60$ \\
\hline Spring & $4 \cdot 48$ & $4 \cdot 50$ & $3 \cdot 06$ & $2 \cdot 41$ & 0.23 & $0 \cdot 18$ & $4.71^{\mathrm{a}}$ & $4 \cdot 57$ \\
\hline Summer & $2 \cdot 85$ & $2 \cdot 97$ & $2 \cdot 29$ & $1 \cdot 34$ & $0 \cdot 16$ & $0 \cdot 15$ & $3 \cdot 01^{\mathrm{b}}$ & $3 \cdot 00$ \\
\hline Autumn & $2 \cdot 96$ & 1.99 & $2 \cdot 81$ & 1.94 & 0.23 & $0 \cdot 19$ & $3 \cdot 19^{b}$ & $2 \cdot 00$ \\
\hline Mean $(n 168)$ & $3 \cdot 38$ & $3 \cdot 19$ & $2 \cdot 67$ & 1.88 & 0.22 & $0 \cdot 18$ & 3.59 & $3 \cdot 23$ \\
\hline $\begin{array}{l}\text { Statistical significance of } \\
\text { difference } \ddagger: P=\end{array}$ & 0.071 & & 0.266 & & $0 \cdot 154$ & & $0 \cdot 067$ & \\
\hline
\end{tabular}

\begin{tabular}{|c|c|c|c|c|}
\hline & \multicolumn{4}{|c|}{ Lycopene } \\
\hline & \multicolumn{2}{|c|}{ Tomatoes } & \multicolumn{2}{|c|}{$\begin{array}{c}\text { Tomatoes and } \\
\text { baked beans }\end{array}$} \\
\hline & Mean & SD & Mean & $\mathrm{SD}$ \\
\hline $\begin{array}{l}\text { Winter } \\
\text { Spring } \\
\text { Summer } \\
\text { Autumn }\end{array}$ & $\begin{array}{l}2 \cdot 81 \\
2 \cdot 10 \\
4 \cdot 60 \\
5 \cdot 14\end{array}$ & $\begin{array}{l}2 \cdot 77 \\
2 \cdot 40 \\
3 \cdot 41 \\
3 \cdot 37\end{array}$ & $\begin{array}{l}3 \cdot 48^{\mathrm{b}} \\
2 \cdot 55^{\mathrm{b}} \\
5 \cdot 07^{\mathrm{a}} \\
5.98^{\mathrm{a}}\end{array}$ & $\begin{array}{l}2 \cdot 86 \\
2 \cdot 50 \\
3 \cdot 40 \\
3 \cdot 94\end{array}$ \\
\hline $\begin{array}{l}\text { Mean }(n 168) \\
\text { Statistical significance of } \\
\text { difference } \$: P=\end{array}$ & $\begin{array}{r}3.66 \\
<0.001\end{array}$ & $3 \cdot 37$ & $\begin{aligned} & 4.27 \\
< & 0.001\end{aligned}$ & 3.46 \\
\hline
\end{tabular}

\begin{tabular}{|c|c|c|c|c|c|c|c|c|}
\hline & \multicolumn{8}{|c|}{$\beta$-Carotene } \\
\hline & \multicolumn{2}{|c|}{ All vegetables } & \multicolumn{2}{|c|}{ Carrots } & \multicolumn{2}{|c|}{ Fruit } & \multicolumn{2}{|c|}{ Total } \\
\hline & Mean & SD & Mean & SD & Mean & SD & Mean & SD \\
\hline Winter & 7.76 & 6.53 & $5 \cdot 70$ & $6 \cdot 26$ & $0 \cdot 33$ & 0.40 & $8 \cdot 09^{\mathrm{a}}$ & 6.60 \\
\hline Spring & 9.86 & $8 \cdot 19$ & 7.35 & $7 \cdot 20$ & $0 \cdot 30$ & 0.42 & $10 \cdot 16^{\mathrm{a}}$ & 8.35 \\
\hline Summer & $10 \cdot 06$ & $8 \cdot 68$ & 7.83 & 8.59 & $0 \cdot 41$ & $1 \cdot 08$ & $10 \cdot 46^{a}$ & $8 \cdot 67$ \\
\hline Autumn & $8 \cdot 15$ & 6.85 & 5.49 & 6.39 & $0 \cdot 16$ & $0 \cdot 16$ & $8 \cdot 32^{\mathrm{a}}$ & 6.93 \\
\hline \multirow{3}{*}{$\begin{array}{l}\text { Mean }(n 168) \\
\text { Statistical significance of } \\
\text { difference } t: P=\end{array}$} & 8.96 & 7.62 & 6.59 & $7 \cdot 18$ & $0 \cdot 30$ & 0.62 & $9 \cdot 26$ & 7.69 \\
\hline & \multirow{2}{*}{\multicolumn{2}{|c|}{0.399}} & \multirow{2}{*}{\multicolumn{2}{|c|}{0.343}} & \multirow{2}{*}{\multicolumn{2}{|c|}{0.332}} & \multirow{2}{*}{\multicolumn{2}{|c|}{$0 \cdot 362$}} \\
\hline & & & & & & & & \\
\hline
\end{tabular}

a. b Mean values with unlike superscript letters were significantly different (paired $t$ test): $P<0.05$.

* For details of subjects and procedures, see pp. 410-411.

$\dagger$ Vegetables minus watercress and spinach.

$\ddagger$ Significance of difference between seasonal means, by one-way ANOVA.

The main source of lutein for most subjects was peas (consumed by about $42 \%$ of subjects during any one season), which provided on average $0.38 \mathrm{mg} / \mathrm{d}$, the equivalent of an average portion being eaten every $3 \mathrm{~d}$. Although broccoli in particular and runner beans and brussels sprouts also contributed to lutein intake, this was subject to seasonal availability or seasonal choice. The main source of lycopene for most subjects was raw tomatoes (consumed by about $76 \%$ of subjects during any one season) which provided an average 
Table 4. Seasonal carotenoid concentrations ( $\mu \mathrm{mol} / \mathrm{l}$ ) of lutein, lycopene and $\beta$-carotene* in blood plasma for a group of UK women aged 50-65 years

(Mean values and standard deviations for forty-two subjects)

\begin{tabular}{|c|c|c|c|c|c|c|}
\hline \multirow[b]{2}{*}{ Season } & \multicolumn{2}{|c|}{ Lutein } & \multicolumn{2}{|c|}{ Lycopene } & \multicolumn{2}{|c|}{$\beta$-Carotene $\dagger$} \\
\hline & Mean & SD & Mean & SD & Mean & SD \\
\hline $\begin{array}{l}\text { Winter } \\
\text { Spring } \\
\text { Summer } \\
\text { Autumn }\end{array}$ & $\begin{array}{l}0.399^{d} \\
0.374^{c} \\
0.493^{a} \\
0.438^{b}\end{array}$ & $\begin{array}{l}0.121 \\
0.150 \\
0 \cdot 181 \\
0 \cdot 161\end{array}$ & $\begin{array}{l}0.266^{\mathrm{b}} \\
0.248^{\mathrm{b}} \\
0.394^{\mathrm{a}} \\
0.374^{\mathrm{a}}\end{array}$ & $\begin{array}{l}0.127 \\
0.121 \\
0.202 \\
0.139\end{array}$ & $\begin{array}{l}0.440^{\mathrm{b}} \\
0.391^{\mathrm{b}} \\
0.685^{\mathrm{a}} \\
0.653^{\mathrm{a}}\end{array}$ & $\begin{array}{l}0 \cdot 251 \\
0 \cdot 215 \\
0 \cdot 404 \\
0 \cdot 355\end{array}$ \\
\hline $\begin{array}{l}\text { Mean }(n 168) \\
\text { Statistical significance of } \\
\text { difference }+: P\end{array}$ & $\begin{array}{r}0.411 \\
<0.001\end{array}$ & 0.140 & $\begin{array}{r}0.320 \\
<0.001\end{array}$ & 0.120 & $\begin{array}{r}0.542 \\
<0.001\end{array}$ & $0 \cdot 270$ \\
\hline
\end{tabular}

a. b. c, d Mean values with unlike superscript letters were significantly different (paired $t$ test): $P \leqslant 0.05$.

* All-trans- $\beta$-carotene.

$\dagger$ For details of subjects and procedures, see pp. 410-411.

$\ddagger$ Significance of difference between seasonal means by one-way ANOVA.

of $1.03 \mathrm{mg} / \mathrm{d}$, the equivalent of an average portion size being eaten approximately every $1-2 \mathrm{~d}$. The main source of $\beta$-carotene was boiled carrots (consumed by about $62 \%$ of subjects during any one season), an average of $2.33 \mathrm{mg} / \mathrm{d}$ and the equivalent of an average size portion being eaten every 2-3 d. However, there were large both within- and betweensubject variations $(\mathrm{CV})$ in carotenoid intake: lutein 55.8 and $60 \cdot 4$, lycopene 66.0 and $52 \cdot 1$, $\beta$-carotene 65.7 and 52.9 respectively.

There was no statistically significant difference in the mean seasonal intake of $\beta$-carotene. Lutein intake was significantly higher during the spring compared with the summer and autumn and there was a significantly higher intake of lycopene during the summer and autumn. The contribution of watercress and spinach to the mean intake of lutein was $20 \%$. Fruits only contributed about $6 \%$ to lutein intake. Tomatoes contributed on average about $86 \%$ of lycopene intake. The average contribution of carrots to $\beta$-carotene intake throughout the year was $71 \%$. The fruit items contributed only about $3 \%$ (see Table 3 ).

Table 4 shows that there were statistically significant differences between the seasonal mean concentrations of plasma lutein, lycopene and $\beta$-carotene, the highest concentrations occurring in the summer and autumn. As with intake, there were large within- and betweensubject variations in blood plasma concentrations of lutein (CV 27.6 and 35.3) lycopene (CV 35.8 and 39.2) and $\beta$-carotene (CV 35.7 and 44.2). Statistical analysis to assess the correlation between carotenoid intake and plasma concentrations for forty-two subjects (see Table 5) showed that there was no significant correlation $(P>0.05)$ for lutein during the winter season, lycopene during the summer or $\beta$-carotene during the winter and autumn. When mean intake from each of the four seasons was compared with the mean seasonal plasma levels the respective correlations were: lutein $P<0.001, r 0.639$; lycopene $P<0.001, r 0.471 ; \beta$-carotene $P=0.002, r 0.447$.

Regression analysis of mean plasma carotenoid concentrations or mean intake of carotenoids with other variables showed that there was an inverse correlation between plasma $\beta$-carotene and BMI, $P=0.004, r 0.406$. There was no correlation $(P>0.05)$ between plasma lutein or lycopene or the intake of lutein, lycopene and $\beta$-carotene and BMI. There was no correlation between mean plasma concentrations of carotenoids and either mean fat intake or blood cholesterol concentrations. 
Table 5. Correlation between intakes of lutein, lycopene and $\beta$-carotene and the corresponding blood plasma concentration for groups of UK women aged 50-65 years*

\begin{tabular}{|c|c|c|c|c|c|}
\hline & Winter & Spring & Summer & Autumn & Mean $\dagger$ \\
\hline \multicolumn{6}{|c|}{ Lutein: statistical significance: } \\
\hline$P$ & $0.068 \ddagger$ & $<0.001$ & 0.031 & $<0.001$ & $<0.001$ \\
\hline$r$ & $0 \cdot 240^{\circ}$ & 0.549 & $0 \cdot 298$ & 0.455 & 0.639 \\
\hline \multicolumn{6}{|c|}{ Lycopene: statistical significance: } \\
\hline$P$ & 0.004 & 0.032 & $0.370 \ddagger$ & $<0.001$ & $<0.001$ \\
\hline$r$ & 0.416 & $0 \cdot 297$ & 0.000 & 0.539 & 0.471 \\
\hline \multicolumn{6}{|c|}{$\beta$-carotene: statistical significance: } \\
\hline$P$ & $0.303 \ddagger$ & 0.003 & 0.043 & $0 \cdot 299 \ddagger$ & $0 \cdot 002$ \\
\hline$r$ & 0.045 & 0.422 & $0-276$ & $0 \cdot 110^{\circ}$ & 0.447 \\
\hline
\end{tabular}

* For details of subjects and procedures, see pp. 410-411.

$\uparrow$ Mean blood concentration and mean intakes from four seasons for forty-two subjects.

$\ddagger$ Not significant.

\section{DISCUSSION}

Our study has shown that the mean concentrations of lutein, lycopene and $\beta$-carotene in the plasma of women were higher during the summer and autumn than during the winter and spring. Similarly, in a survey of 2000 British adults (Thurnham \& Flora, 1988) the concentration of these carotenoids tended to be lowest between January and March and highest during the last 6 months of the year. A study on eighteen Spanish subjects (Olmedilla et al. 1994) showed the highest mean levels of lutein occurred in the spring in women and in the summer in men. There was no significant seasonal variation in lycopene concentrations and the highest mean concentrations of $\beta$-carotene occurred in the summer in both men and women. In 942 Finnish men the lowest serum $\beta$-carotene concentrations were observed during April and May and the highest during October and November (Rautalahti et al. 1993). Carotenoid concentrations in a Japanese population tended to be higher in the winter (Ito et al. 1990). The concentration of $\beta$-carotene in both men and women in Germany (Heseker et al. 1992) tended to be lower during the spring compared with the summer, autumn or winter. No clear seasonal changes were observed in the lutein plus zeaxanthin, lycopene or $\beta$-carotene concentrations of a group of twenty-nine American subjects (Cantilena \& Nierenberg, 1989). Little seasonal difference was detected in the carotenoid concentrations of the Chinese (Zheng et al. 1989). Differences between countries are probably a reflection of the types and availability of foods eaten.

In the UK, about $70 \%$ of the intake of $\beta$-carotene equivalents comes from vegetables, approximately $1.6 \mathrm{mg} / \mathrm{d}$ and $3 \%$, approximately $0.07 \mathrm{mg} / \mathrm{d}$, from fruits and nuts (Gregory et al. 1990). The average intake of $\beta$-carotene equivalents (seventy-nine subjects) from selected vegetable and fruit items in the present study, calculated from McCance and Widdowson's The Composition of Foods (Holland et al. 1991), was approximately 1.6 and $0.05 \mathrm{mg} / \mathrm{d}$ respectively. Calculated from the analysed data (Hart \& Scott, 1995), the average intake of all-trans- $\beta$-carotene from vegetables was $2.3 \mathrm{mg} / \mathrm{d}$ and from fruit $0.09 \mathrm{mg} / \mathrm{d}$. The difference between the 'calculated' and 'analysed' intake is almost wholly explained by the higher average 'analysed' value for all-trans- $\beta$-carotene in carrots. The degree of association between intake and blood carotenoid concentrations (see Table 5) was to an extent dependent on season. The correlations between mean intake and mean blood plasma concentrations were : lutein $0 \cdot 639$, lycopene 0.471 and $\beta$-carotene 0.447 . Comparison with other published information (Russell-Briefel et al. 1985; Roidt et al. 1988; Stryker et al. 1988; Bolton-Smith et al. 1991; Coates et al. 1991; Ascherio et al. 1992; Forman et al. 
1993; Yong et al. 1994) is difficult because these studies were based on data from one timepoint only and methods of measuring intake in these studies varied. Also, our measurement of intake was based on selected vegetables and fruits which were sources of lutein, lycopene and $\beta$-carotene. Furthermore, in some studies the intakes of $\beta$-carotene were expressed as 'carotene' estimated from the vitamin A activity of foods. In general, correlations for $\beta$-carotene and lycopene in the present study are similar to those published more recently (Forman et al. 1993; Yong et al. 1994). However, it should be noted that in these studies the strength of the correlation is dependent on the method of dietary assessment. Our values for lutein are higher $(r 0.64 \mathrm{v}$. approximately 0.4$)$. This may be a reflection of the more discrete analysis of lutein in vegetables recently carried out in our laboratory (Hart \& Scott, 1995).

The findings of the study reported here and those reported by others (Tangney et al. 1987; Forman et al. 1993; Olmedilla et al. 1994) have demonstrated considerable withinsubject variation in intake and plasma carotenoid concentrations. Results from a pilot study (Tangney et al. 1987) suggested that day-to-day individual variation in dietary intake and blood concentrations of fat-soluble vitamins can constitute an important source of error in the assessment of the association between dietary intake, blood status and disease risk.

Recently H. Tamai, T. Morinobu, T. Murata, M. Hozumi, T. Kuno, H. Moji, M. Manago \& M. Mino (unpublished results) have shown that the plasma $\beta$-carotene concentrations but not the plasma $\alpha$-tocopherol concentrations in Japanese children were correlated with percent obesity; after dieting and exercise to reduce body weight the plasma $\beta$-carotene concentration was gradually increased, while $\alpha$-tocopherol concentrations were unchanged. Our findings that $\beta$-carotene, but not lutein or lycopene plasma concentrations or intake of lutein, lycopene or $\beta$-carotene, was inversely correlated with BMI, suggests that $\beta$-carotene is behaving differently from other carotenoids. It may be that although there is a similar intake by obese and non-obese subjects, $\beta$-carotene is being removed from the plasma to another body pool, possibly the adipose tissue, at a faster rate in the obese subjects. The fact that there was no correlation between BMI and plasma lutein or lycopene concentrations may also suggest a different degree of tissue specificity for these carotenoids.

As far as we are aware this is the first study to assess the association between the plasma concentration of carotenoids and intake of carotenoids at different seasons during the year. The variation in correlations reported in various studies may well reflect the problems in the accurate measurement of the intake of micronutrients. Furthermore, the relatively modest correlations in these studies may also be explained by the vagaries of dietary and biochemical measurements, in particular by the number of independent measurements required to limit the attenuation of the diet $v$. plasma correlation, the provitamin A activity of $\beta$-carotene and the limited understanding of carotenoid metabolism.

The intake study was supported in part by the Ministry of Agriculture Fisheries and Food and the Cancer Research Campaign. The authors are grateful for the skilled technical assistance of Mark Boyd in the analysis of the blood plasma. This study was supported by the Ministry of Agriculture Fisheries and Food.

\section{REFERENCES}

Ascherio, A., Stampfer, M. J., Colditz, G. A., Rimm, E. B., Litin, L. \& Willett, W. C. (1992). Correlations of Vitamin $\mathrm{A}$ and $\mathrm{E}$ intakes with the plasma concentrations of carotenoids and tocopherols among American men and woman. Journal of Nutrition 122, 1792-1801.

Bingham, S. A., Gill, C., Welch, A., Day, K., Cassidy, A., Khaw, K. T., Sneyd, M. J., Key, T. J. A., Roe, L. \& Day, N. E. (1994). Comparison of dietary assessment methods in nutritional epidemiology: weighed records v. $24 \mathrm{~h}$ recalls, food frequency questionnaires and estimated-diet records. British Journal of Nutrition $\mathbf{7 2}$, 619-643. 
Block, G., Patterson, B. \& Subar, A. (1992). Fruit, vegetables, and cancer prevention: A review of epidemiological evidence. Nutrition and Cancer 18, 1-30.

Bolton-Smith, C., Casey, C. E., Gey, K. F., Smith, W. C. S. \& Tunstall-Pedoe, H. (1991). Antioxidant vitamin intake assessed using a food-frequency questionnaire : correlation with biochemical status in smokers and nonsmokers. British Journal of Nutrition 65, 337-346.

Cantilena, L. R. \& Nierenberg, D. W. (1989). Simultaneous analysis of five carotenoids in human plasma by isocratic high performance liquid chromatography. Journal of Micronutrient Analysis 49, 127-145.

Chopra, M., Willson, R. L. \& Thurnham, D. I. (1993). Free radical scavenging activity of lutein in vitro. In Carotenoids in Human Health [L. M. Canfield, N. I. Krinsky and J. A. Olson, editors]. Annals New York Academy of Sciences 691, 246-249.

Coates, R. J., Eley, J. W., Block, G., Gunter, E. W., Sowell, A. L., Grossman, C. \& Greenberg, R. S. (1991). An evaluation of a food frequency questionnaire for assessing dietary intake of specific carotenoids and vitamin $\mathrm{E}$ among low income black women. American Journal of Epidemiology 134, 658-671.

Di Mascio, P., Murphy, M. E. \& Sies, H. (1991). Antioxidant defense systems: the role of carotenoids, tocopherols and thiols. American Journal of Clinical Nutrition 53, Suppl., 194S 200 S.

Forman, M. R., Lanza, E., Yong, L.-C., Holden, J. M., Graubard, B. I., Beecher, G. R., Melitz, M., Brown, E. D. \& Smith, J. C. (1993). The correlation between two dietary assessments of carotenoid intake and plasma carotenoid concentrations: application of a carotenoid food-composition database. American Journal of Clinical Nutrition 58, 519-524.

Gregory, J., Foster, K., Tyler, H. \& Wiseman, M. (1990). The Dietary and Nutritional Survey of British Adults, p. 129. London: H.M. Stationery Office.

Hart, D. J. \& Scott, K. J. (1995). Development and evaluation of an Hplc method for the analysis of carotenoids in foods, and the measurement of the carotenoid composition of commonly consumed vegetables and fruits in the UK. Food Chemistry 54, 101-111.

Heseker, H., Schneider, R., Moch, K. J., Kohlmeir, M. \& Kubler, W. (1992). Vitaminversorgung erwachsener in der Bundesrepublik Deutschland (Vitamin Intakes of Adults in the Republic of Germany). Wissenschaftlichter Fachverslag. Niederkleen, Germany: Fleck.

Holland, B., Welch, A. A., Unwin, I. D., Buss, D. H., Paul, A. A. \& Southgate, D. A. T. (1991). McCance \& Widdowson's The Composition of Foods, 5th ed. Cambridge: The Royal Society of Chemistry.

Ito, Y., Ochiai, J., Sasaki, R., Suzuki, S., Kusuhara, Y., Morimitsu, Y., Otani, M. \& Aoki, K. (1990). Serum concentrations of of carotenoids, retinol, and $\alpha$-tocopherol in healthy persons determined by high-performance liquid chromatography. Clinica Chimica Acta 194, 131-144.

Olmedilla, B., Granado, F., Blanco, I. \& Rojas-Hidalgo, E. (1994). Seasonal and sex-related variations in six serum carotenoids, retinol, and $\alpha$-tocopherol. American Journal of Clinical Nutrition 60, 106-110.

Rautalahti, M., Albanes, D., Haukka, J., Roos, E. \& Virtamo, J. (1993). Seasonal variation of serum levels of $\beta$-carotene and $\alpha$-tocopherol. In Food and Cancer Prevention: Chemical and Biological Aspects, p. 146 [K. W. Waldron, I. T. Johnson and G. R. Fenwick, editors]. Cambridge: The Royal Society of Chemistry.

Roidt, L., White, E., Goodman, G. E., Wahl, P. W., Omenn, G. S., Rollins, B. \& Karbeck, J. M. (1988). Association of food frequency questionnaire estimates of vitamin A intake with serum vitamin A levels. American Journal of Epidemiology 128, 645-654.

Russell-Briefel, R., Bates, M. W. \& Kuller, L. H. (1985). The relationship of plasma carotenoids to health and biochemical factors in middle-aged men. American Journal of Epidemiology 122, 741-749.

Steimetts, K. A. \& Potter, J. D. (1991). Vegetables, fruits and cancer. 1. Epidemiology (review). Cancer Causes and Control 1, 325-357.

Stryker, W. S., Kaplin, L. A., Stein, E. A., Stampfer, M. J., Sober, A. \& Willett, W. C. (1988). The relation of diet, cigarette smoking, and alcohol consumption to plasma $\beta$-carotene and $\alpha$-tocopherol levels. American Journal of Epidemiology 127, 283-296.

Tangney, C. C., Shekelle, R. B., Raynor, W., Gale, M. \& Betz, E. P. (1987). Intra and inter variation in measurements of $\beta$-carotene, retinol, and tocopherols in diet and plasma. American Journal of Clinical Nutrition 45, 746-749.

Terao, J. (1989). Antioxidant activity of $\beta$-carotene related carotenoids in solution. Lipids 24, 659661

Thurnham, D. I. \& Flora, P. S. (1988). Do higher Vitamin A requirements in men explain the differences between sexes in plasma provitamin A carotenoids and retinol. Proceedings of the Nutrition Society 47, $181 \mathrm{~A}$.

Thurnham, D. I., Smith, E. \& Flora, P. S. (1988). Concurrent liquid-chromatographic assay of retinol, $\alpha$ tocopherol, $\alpha$-carotene, $\beta$-carotene, lycopene, and $\beta$-cryptoxanthin in plasma, with tocopherol acetate as internal standard. Clinical Chemistry 34, 377-381.

Yong, L. C., Forman, M. R., Beecher, G. R., Graubard, B. I., Campbell, W. S., Reichman, M. E., Taylor, P. R., Lanza, E., Holden, J. M. \& Judd, J. T. (1994). Relationship between dietary intake and plasma concentrations of carotenoids in premenopausal women: application of the USDA-NCI carotenoid food-composition data base. American Journal of Clinical Nutrition 60, 223-230.

Zheng, S., Ershow, A. G., Yang, C. S., Guangyi, L., Rongsheng, L., Hui, L., Zou, X., Liu, X., Song, L., Qing, Q., Yang, Q., Sun, Y., Li, J. \& Blot, W. (1989). Nutritional status in Linxian, China : effects of season and supplementation. International Journal of Vitamin Nutrition Research 59, 190-199. 